\title{
手術不適応癌の新しい治療
}

\section{5. 手術不能胃癌に対する抗癌化学療法の進歩}

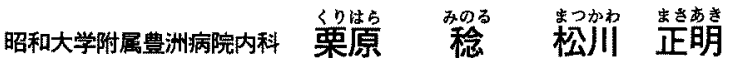

Key words :手術不適応，胃がん，抗がん化学療法

\section{はじめに}

本邦において依然として癌死亡の第一位を占め る胃癌は，診断法や手術法の進歩にも拘らず，発 見時既に肝転移，リンパ節転移，癌性腹水などで 手術不適応な症例（原発巣のある場合と原発巣切 除後の再発の場合）があとを絶たない。さらに70 歳以上の高齢者の進行胃癌では，明らかな転移が なくても，心，肺，肝，腎などの機能低下や重篤 な合併症のある症例や手術拒否例が少なくなく， 抗癌化学療法の適応となっている.

従来, 使用さ机る抗癌薬は，5-FUとその誘導体 (tegafur, UFT, 5'-DFUR など) とMMC (mitomycin C), ADM (adriamycin), ACNUな どの 2 薬ないし 3 薬の併用療法が主体で, 奏効率 も筆者らが中心になって作成した胃癌化学療法効 果判定基準（後述）に従うと, 施設外検閲を厳密 に実施した我々の共同研究では，良い成績でも $25 \%$ どまりで，まれに 3 年以上の生存例が得られ るにしろ，50\%生存期間は約 6 力月に過ぎなかっ た. 特にtegafur +MMCとUFT+MMCの無作為 化比較試験は，厚生省がん研究助成金を得て，筆 者らの施設が事務局を担当し，1985年 1 月〜 1988 年10月に手術不能の理由を敛密にチェック後登録 された186例のうち, 不適格例, 不完全例を除いた 169例の治療結果で, これが当時最も沉用されてい た胃癌化学療法の実態であり, 限界を示す成績と 評価された1)。ところが, 欧米でCDDP (cis- diamine dichloroplatirum）を含蒠多薬併用療法 (例えば, EAP = etoposide, ADM, CDDPの 3 者 併用 ${ }^{2)}$ ， FAP $=5-\mathrm{FU}, \mathrm{ADM}, \mathrm{CDDP}$ の 3 者併用 ${ }^{3)}$ ) で，触診主体の効果判定法が我々のそれと異なる にしろ，奏効率が35 60\%の成績が報告され，本 邦でもCDDPを導入した多剂併用で奏効率の上昇 が確認されて, 胃癌化学療法は新たな転換期を迎 えた。ここでは，我々の成績を中心に最近の知見 について報告する。

\section{1. 胃癌化学療法効果判定基準}

我々は，長年にわたって化学療法による原発胃 癌の効果判定は胃X線像, 胃内視鏡像によること, 及び計測不可能な場合には, 樎凹面や周堤の変化, さらにびまん浸潤胃癌では胃X線像による罹患部 面積の拡大率によることなどを主張してきた が4), 胃癌研究会では規約委員会を設けて検討し, 胃癌取扱い規約 (改訂第11版) で1985年 4 月以来, 胃X線像ないし内視鏡像で計測可能なa病変, 計測 困難だが評価可能なb病変,びまん浸潤性胃癌はc 病変にわけて効果判定することをきめた．今回， 表 1 に要約したように改正した5)。いずれも，胃X 線像や胃内視鏡像で 4 週間以上の間隔をおいて效 果を確認することが条件づけられている。転移巣 に対するUS (ultrasonography) やCT (computerized tomography）による場合も同様である. 
表 1. 胃癌の化学漂法効果判定基準(胃癌取扱い規約，改訂第12版)

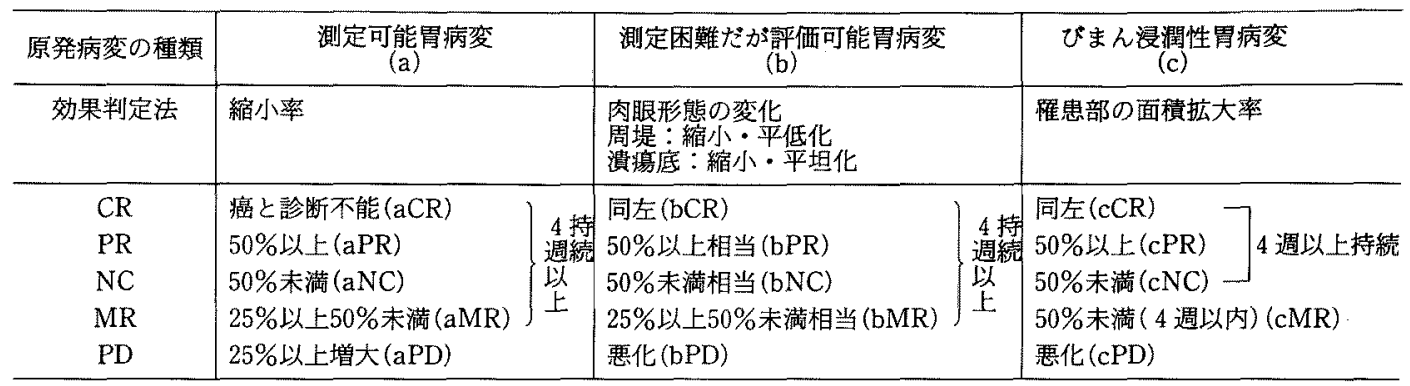

$\mathrm{CR}$ : complete response(著効) $\mathrm{PR}$ : partial response(有効) $\mathrm{NC}:$ no change(不変)

MR: minor response (CR, PRの条件に满たないが, NCの基準のなかでやや奏効度が高いと評価される症例)

$\mathrm{PD}$ : progressive disease(進行)

\section{2. $5^{\prime}$-DFUR + CDDP療法}

我々が中心となって実施した厚生省がん研究助 成金「固形がんの集学的治療の研究」班胃癌内科 グルーブよる共同研究である. 5'-DFUR 1400 $\mathrm{mg} / \mathrm{m}^{2} /$ 日の 4 日間投与 3 日間休薬と第 5 日に $\mathrm{CDDP} 80 \mathrm{mg} / \mathrm{m}^{2} /$ 週（点滴時間は 2 時間を標準と する）の 3 週ごと投与で, 対象は原発巣切除不能 ないし術後（絶対非治癒切除, 再発）胃癌で, PS は $0 \sim 3$, 年齢75歳末満で, 既往にいかなる抗癌 化学療法もない新鮮例とした。 29例を登録した時 点で，極めて重䉆な腎障害と下浰の合併症例がで たため, 班内の効果安全性評価委員会からプロト コールの見直しを求められた.この際, 実際と予 定の総投与量の比率 (relative performance，RP)
を2 クールまでで求めたところ, 5'-DFUR 0.83 , CDDP 0.88であった。これらを参考に，5'-DFUR $1,400 \mathrm{mg} / \mathrm{m}^{2} /$ 日の 4 日間投与 10 日間休薬, 第 5 日 にCDDP $80 \mathrm{mg} / \mathrm{m}^{2} /$ 週の 4 週ごと投与を 1 クール とすることに変更し，以後52例を登録した。この 治療結果を表 2 に示した. ともに目標とした期待 奏効率 $30 \%$ 上まわったが，両者に有意差はな かった。 また両治療間に, 性比, 年齢, PS (performance status), Borrmann型分類, 組織型, 癌の 体内の拡がり別にみた病型など, 背景因子には有 意差がみられなかった，対象部位別の効果（表 3) には有意差なく, 副作用は, 新法で下痢が有意に 少なく, 悪心, 嘔吐, 全身倦急, 造血障害も有意 差はないものの, 頻度も減り程度も軽くなってい た. 新法の 2 クールまでのRPは, 5'-DFUR 0.96, CDDP 0.91 と良好であった. 治療開始後の $50 \%$ 生

表 2. 症例の取扱い及び抗腫瘍効果判定

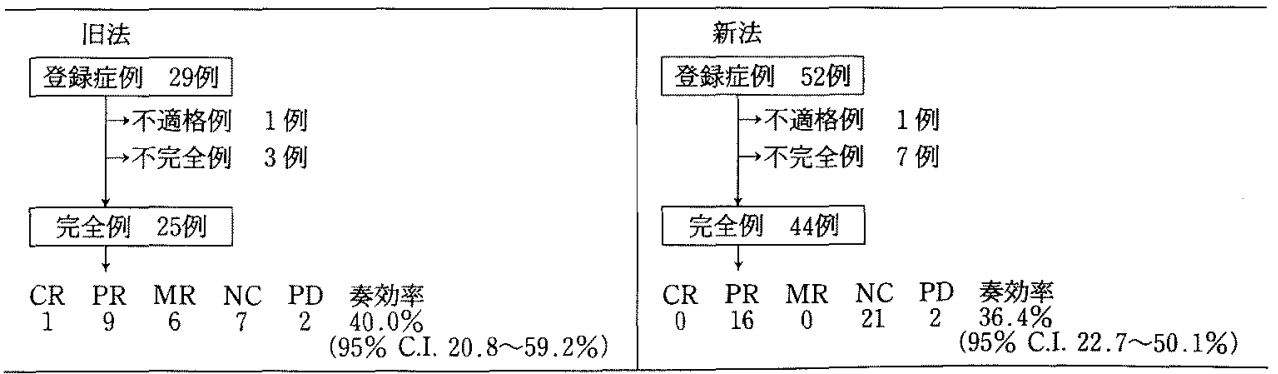


表 3. 対象部位別効果

\begin{tabular}{|c|c|c|c|}
\hline & 旧 法 & 新 法 & 榆定 * \\
\hline 原発巣 & $23.8 \%(5 / 21)$ & $32.6 \%(14 / 43)$ & N.S. \\
\hline $\mathrm{a}$ 病変 & $33.3 \%(2 / 6)$ & $54.5 \%(6 / 11)$ & N.S. \\
\hline $\mathrm{b}$ 病変 & $30.0 \%(3 / 10)$ & $41.2 \%(7 / 17)$ & N.S. \\
\hline $\mathrm{c}$ 病変 & $0 \%(0 / 5)$ & $7.1 \%(1 / 15)$ & N.S. \\
\hline \multicolumn{4}{|l|}{ 転移巣 } \\
\hline 肝 & $36.4 \%(4 / 11)$ & $47.1 \%(8 / 17)$ & N.S. \\
\hline 腹膜内リンパ節 & $50.0 \%(4 / 8)$ & $30.8 \%(4 / 13)$ & N.S. \\
\hline \multirow[t]{2}{*}{ その地 } & $20.0 \%(4 / 8)$ & $7.7 \%\left(1^{*} / 13\right)$ & N.S. \\
\hline & *肺 & ${ }^{*}$ 大腸 & \\
\hline 腹水 & $100 \%(3 / 3)$ & $60.0 \%(3 / 5)$ & N.S. \\
\hline
\end{tabular}

*Fisher's exact test

存期間は，ともに9.1力月，1 年生存率は，旧法 $40 \%$ ，新法 $32 \% ， 2$ 年生存率は，旧法 $17 \%$, 新法 15\%であった．奏効例に限ると，50\%生存期間は 旧法（10例）で9.75力月に対し，新法（16例）で は15.3力月と良好であった。

本試験では，患者の自己記入式によるQOL (quality of life) 調查を実施したので，偶然に旧 法, 新法のQOLを比較できた ${ }^{6)}$. 著明な差が出たの は，食欲，気分，全体の調子などであった．個人 のQOL合計点が治療前值より 2 割以上改善し，か つ 4 週以上持続すれば「改善」, 個人のQOL合計点 が治療前值より 2 割以上悪化し，かつ 4 週以上持 続すれば「悪化」この中間を「不変」とすると, $50 \%$ 生存期間が，旧法では改善例 ( 3 例)で469日， 不変例（4 例）で314日, 悪化例（5例）で258日, 新法では改善例 ( 7 例) で814日，不変例（5例） で230日，悪化例 ( 2 例) で75.5日と, QOLの改善
表 4、l-ロイコボリン・5-FU併用療法の投与方法

\begin{tabular}{|c|c|c|}
\hline & lーロイコポリン & $5-F U$ \\
\hline A 法 & $\begin{array}{l}250 \mathrm{mg} / \mathrm{m}^{2} / \text { 遇 } 1 \text { 回 } \\
2 \text { 時間点滴静注 }\end{array}$ & $\begin{array}{l}600 \mathrm{mg} / \mathrm{m}^{2} / \text { 週 } 1 \text { 回 } \\
\text { l.ロ 開 } \\
\text { 始 } 1 \text { 時間後 } \\
\text { bolus i.v. }\end{array}$ \\
\hline B法 & $\begin{array}{l}100 \mathrm{mg} / \mathrm{m}^{2} / \text { 日 } \times 5 \text { 日間 } \\
\text { bolus i.v. }\end{array}$ & $\begin{array}{l}370 \mathrm{mg} / \mathrm{m}^{2} / \text { 日 } \times 5 \\
\text { bolus i.v. }\end{array}$ \\
\hline C法 & $\begin{array}{l}10 \mathrm{mg} / \mathrm{m}^{2} / \text { 日 } \times 5 \text { 日間 } \\
\text { bolus i.v. }\end{array}$ & $\begin{array}{l}370 \mathrm{mg} / \mathrm{m}^{2} / \mathrm{B} \times 5 \\
\text { bolus i.v. }\end{array}$ \\
\hline
\end{tabular}

度は生存期間に反映する結果となった。

これに前後して, 施設を異にする共同研究で, $5^{\prime}$-DFUR + CDDP + MMC 03 剂併用7), UFT +

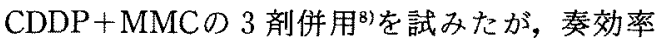
惊，前者で26.1\%，後者で $23.5 \% ， 2$ コース以上 投与できた例の奏効率は，前者で35.3\%（6/17）, 後者で36.4\%(4/11) で薬物の投与量, 投与法に 工夫の必要があると思われた。

\section{3. 期待される新治療法}

まずロイコボリンが5-FUの効果を増強するbiochemical modulationで, 欧米の大腸癌治療法に ならって, 表 4 の 3 法が胃癌に実施され，奏効率 は，A法で37\% (10/27)，B法で24.1\% (7/29)， C法は0/17で途中で登録を中止した ${ }^{9} .50 \%$ 生存期 間は，A法で287日，B法で240日，C法で176日で あった。 主な副作用は, A法で下痢, B法で口内炎, 白血球隇少がともに70\%前後にみられる。

CPT-11(トポイソメラーゼ1型阻害薬) は，図に 示すようにSN-38になって効果を発揮するが，A

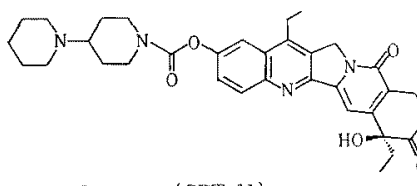

Irinotecan (CPT-11)

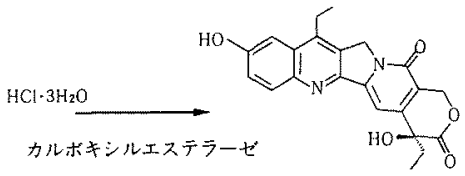

$\mathrm{SN}-38$

用法・用量

図、塩酸イリノテカン（CPT-11）および活性代謝物SN-38の構造

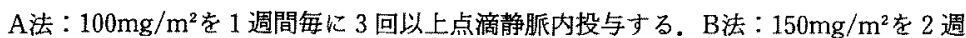
間毎に2回以上点滴静脈内投与する。 
表 5.CPT-11後期第11相臨床試駼（胃癌）

\begin{tabular}{c|c|c|c|c|c|c|c|c|c}
\hline & 適格例 & 完全例 & CR & PR & MR & NC & PD & \multicolumn{2}{|c}{ 奏効率 $(\%)$} \\
\cline { 7 - 9 } & & & & & & & \\
\hline 全体 & 76 & 60 & 0 & 14 & 4 & 23 & 19 & $18.4 \%^{*}$ & $23.3 \%{ }^{* *}$ \\
投与方法 & & & & & & & & & \\
A法 & 38 & 28 & 0 & 7 & 1 & 10 & 10 & $18.4 \%$ & $25.0 \%$ \\
B法 & 38 & 32 & 0 & 7 & 3 & 13 & 9 & $18.4 \%$ & $21.9 \%$ \\
前化学潦法 & & & & & & & & & \\
無 & 20 & 15 & 0 & 5 & 1 & 7 & 2 & $25.0 \%$ & $33.3 \%$ \\
有 & 56 & 45 & 0 & 9 & 3 & 16 & 17 & $16.1 \%$ & $20.0 \%$ \\
\hline 5-FU & 48 & 37 & 0 & 7 & 3 & 14 & 13 & $14.6 \%$ & $18.9 \%$ \\
CDDP & 37 & 31 & 0 & 6 & 0 & 10 & 15 & $16.2 \%$ & $19.4 \%$ \\
\hline
\end{tabular}

$95 \%$ 信頼区間 $* 9.7 \sim 27.1 \% ，{ }^{* *} 12.6 \sim 34.0 \%$

法とB法が検討された，奏効率は，全体で $23.3 \%$ ， A法とB法に有意差はなく，前治療有りでも20\% で, 文献上の5FU, CDDP単独の成績と同等であっ た (表 5$)^{10)}$. 将来, 適切な併用法が期待される.

\section{おわりに}

近年, 白血球数減少にはG-CSF, 悪心, 嘔吐に は $5-\mathrm{HT}_{3}$ 受容体拮抗薬の併用が有効であることが 確認された。 今後は, これらの併用によりdose intensityを高め, 奏効率の上昇, 生存期間への反 映をはかることが求められる。そしてまた確実に 手応えのある症例が増えてきているので，患者の QOLの評価も必要である. そのために筆者らが厚 生省がん研究助成金を得て作成した質問票 ${ }^{11}$ が追 試，検討されることを切望する。

\section{文献}

1) Kurihara $M$, et al: A cooperative randomized study on tegafur plus mitomycin $\mathrm{C}$ versus com bined tegafur and uracil plus mitomycin $\mathrm{C}$ in the treatment of advanced gastric cancer. Jpn J Cancer Res $82: 613,1991$.

2) Preusser $P$, et al: Phase Il study with the combination etoposide, doxorubicin, and cisplatin in advanced measurable gastric cancer. J
Clin Oncol $7: 1310,1989$.

3) Moertel CG, et al: A phase II study of combined 5-fluorouracil, doxorubicin, and cisplatin in the treatment of advanced upper gastrointestinal adenocarcinomas. J Clin Oncol 4: 1053, 1986.

4）栗原 棇: IVA, 腫㰾効果判定基準, 胃癌の化学 療法, 栗原 稔, 他編, 初版, 新興医学出版社, 東京, 1981, p43.

5）胃癌研究会編：第 4 部III， 6, 治療効果判定，腤 潞取扱規約(改訂第12版)，金原出版，東京，1993， p116.

6) 丞原 稔, 清水弘之：QOL 評価の実際一がん薬物 㙩法に捄ける QOL 筫問票の作製一.ターミナル ケア $2: 233,1992$.

7）福山悦男，他：切除不能進行胃癌见対する $5^{\prime}$ DFUR + CDDP + MMC 療法. Oncologia 26: $345,1993$.

8）岩崎良三，他：切除不能進行・再発胃癌に対する UFTPM (UFT $\cdot C D D P \cdot M M C)$ 療法の検討. 癌と 化学療法 20:1179, 1993.

9）佐々木恒雄：Leucovorin-5-FU 併用療法. 癌と化 学療法 19: 954, 1992.

10）二ツ木浩一，他：再発・進行胃癌に対する塩酸仡 リノテカン (CPT-11)の後期第II相臨床試験。癌上 化学察法 $21: 1033,1994$.

11）江口研二，他：がん薬物療法に枋けるQOL 調查 票. 日癌治 28：1140, 1993. 